Three experienced librarians will draw on theoretical as well as practical and administrative experience to address the crucial first steps that must be taken when embarking on research.

- "Psychological Barriers to Research," Brian Nielsen, Northwestern University.

- "Creating a Supportive Environment for Research," Maureen Pastine, Washington State University.

- "Taking the First Step to Research," James Neal, Pennsylvania State University.

A panel of five librarians, each with diverse research interests and publication experience will cover an array of personal considerations you need to work through before beginning research.

- "Identifying a Research Problem," Margaret Porter, Notre Dame.

- "Making the Transition from Library School to the Profession," Bart Clark, University of Illinois.
- "The Advisability of Selecting a Professional Network and Finding Time and Funds to Complete Projects," Mary M. Huston, Brainerd Community College.

- "The Appropriate Timing for Consultation to Refine Methodologies for Presenting Results to Audiences and Publications," Tim Richards, Vanderbilt University.

- "The Benefits of Research to Daily Professional Activities," Beth Sandore, University of Illinois.

- "Putting the Pieces Together," JoAn Segal, ACRL Executive Director, and Tim Richards, Vanderbilt University.

Betsy Baker, Northwestern University, will moderate the workshop.

Date: April 8, 1:30 p.m.-5:00 p.m.; April 9, 9:00 a.m. $-12: 00$ p.m.

Location: Cincinnati Convention Center.

Fee: ACRL Members, $\$ 155$; Non-members, $\$ 195$.

\title{
Travel and Hotel Information
}

\section{Getting to Cincinnati is easy}

Whether you fly or drive to Cincinnati, it couldn't be easier. The Greater Cincinnati International Airport (GCIA) is one of the most efficient airports in the country. Don't be surprised when you hear the pilot welcoming you to Kentucky, because the GCIA stretches over 5,000 areas of land in Northern Kentucky. Major national and regional airlines schedule flights through GCIA and it serves as a major hub for Delta Air Lines, the official conference carrier. While catching your breath upon arrival, take a peek at the famous Mosaic murals, sprinkled throughout the airport. They depict the historical influence of industry on Cincinnati.

After you arrive at the airport, you will find taxi and bus service available for the 15-minute trip into downtown Cincinnati. Jetport Shuttle Express buses go to and from downtown hotels every 30 minutes on the hour and half hour between 5:30 a.m. and 11:00 p.m., Monday through Friday; every hour between 6:30 a.m. and 11:30 p.m. on Saturday; and every 30 minutes until 11:00 p.m. on Sunday. The fare is $\$ 7$ one way, $\$ 11$ round trip. The Airport Taxi Cab Company provides service at a rate of $\$ 18$ per cab (1-4 people) to downtown Cincinnati. Rental car agencies are located in the baggage claim area in each of the three terminals.

\section{Discounted airfares to Cincinnati}

T.V. Travel, Inc., the official travel agency for the American Library Association for the past eleven years, is offering special fares for travel to Cincinnati. All attendees traveling round trip to the conference between April 3 and April 10, 1989, are eligible for special fares on Delta Air Lines. You will receive a $40 \%$ discount off the coach fare, or a $5 \%$ discount off the lowest fare. You must purchase tickets within 24 hours of booking for the lowest fares and at least seven days in advance for the $40 \%$ discount.

The lowest fares are non-refundable and do not allow any changes once issued. Penalty charges for changing or canceling also apply on the seven-day advance tickets.

In addition to the special airfares, you will receive $\$ 150,000$ in free flight insurance when booking your trip with $T . V$. Travel, Inc.

Call T.V. Travel for reservations and further information, toll free (800) 826-9682; in Illinois call collect, (312) 899-1112, Monday through Friday, 7:45 a.m. $-6: 30$ p.m., CST. Ask for ACRL Conference reservations.

\section{Arriving by car, train or bus}

Cincinnati is an easy day's drive for about $60 \%$ of the nation's population. The city is served by four interstate highways and is a hub for numerous other large roadways as well. Amtrak trains arrive and depart on a daily basis going east or west at the River Road station. Greyhound serves as the cross country bus service for Cincinnati.

\section{Getting around in Cincinnati}

Once you arrive in Cincinnati, you will find the Convention Center, shopping, fine dining and cultural attractions all within a five-minute walk. And for one thin dime you may board the "Downtowner," a service of Queen City Metro, and get off and on at any spot along its central downtown 


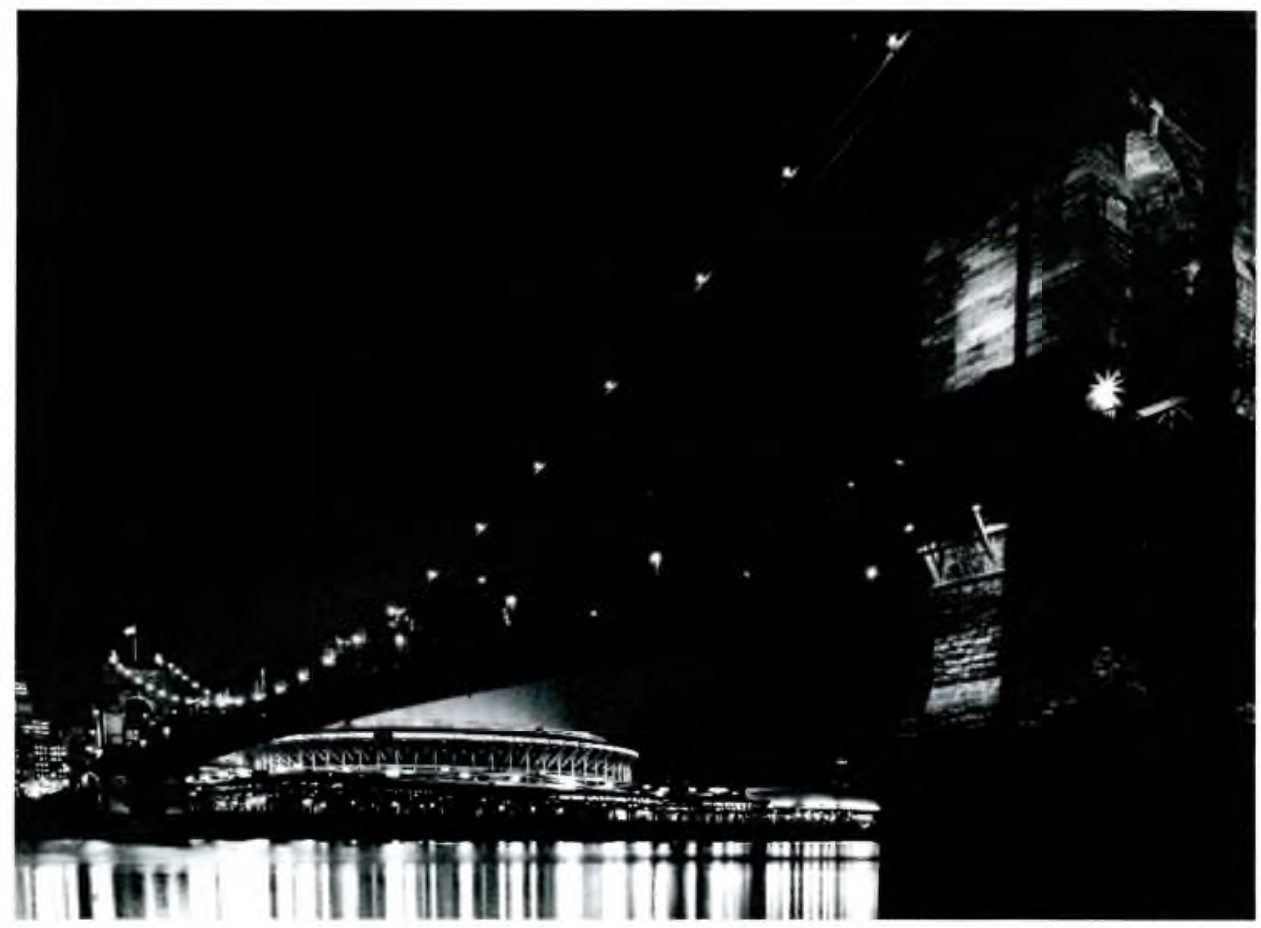

The graceful span of the John A. Roebling Suspension Bridge is a contrast of Old World charm against the skyline of downtown Cincinnati.

route. Queen City Metro also provides service to about 45 other routes at various prices.

\section{Conference hotels}

All four conference hotels are conveniently linked to the Convention Center by the Skywalk Connection. Rates at the hotels range from $\$ 75-\$ 95$ for a single and from $\$ 87-\$ 112$ for a double. A $10 \%$ sales tax must be added to all prices. Reservations for rooms at the official conference hotels are being handled by the Cincinnati Visitors and Convention Housing Bureau. Use the form in the preliminary program to reserve a room. Deadline for reservations is March 6, 1989.

The very closest hotel to the Convention Center is the Clarion, just 50 steps away. Also close by the Center is the Hyatt Regency Cincinnati, which offers many rooms with sweeping river views. The Hyatt is the Headquarters Hotel.

Entering the Omni Netherland Plaza is like entering a movie set, for this hotel is one of the finest remaining examples of Art Deco design in the United States. The Terrace Hilton has very much the feel of an exclusive club, with all wood paneling and executive color schemes.

\section{Placement Service}

A placement service will be provided by the ALA Office for Library Personnel Resources on April 5-7, 9:00 a.m. $-5: 00$ p.m. It will be located in the Albert B. Sabin Convention Center.

Although registrations will be accepted at the conference, job seekers and employers are strongly urged to preregister. The deadline for preregistration is March 15, 1989. To request forms (indicate employer or job seeker), write: ACRL National Conference, Placement, 50 East Huron Street, Chicago, IL 6061l. If requesting one copy, enclase a self-addressed, stamped envelope (\#10). Enclose a mailing label for multiple copies.

Interview facilities will be provided. Employment policy prohibits the acceptance of job listings which bear discriminatory specifications with respect to race, creed, age, color, sex or national origin. A salary range must be listed. 